\title{
Changing clinical behaviour by making guidelines specific
}

Susan Michie, Marie Johnston

Efforts to get doctors to follow guidelines have overlooked the importance of clear and concise recommendations

The problems of getting people to act on evidence based guidelines are widely recognised. ${ }^{1}$ An overview of 41 systematic reviews found that the most promising approach was to use a variety of interventions including audit and feedback, reminders, and educational outreach. ${ }^{1}$ The effective interventions often involved complicated procedures and were always an addition to the provision of guidelines. None of the studies used the simplest intervention-that is, changing the wording of the guidelines. We examine the importance of precise behavioural recommendations and suggest how some current guidelines could be improved.

\section{Importance of wording}

The wording of a behavioural instruction affects the likelihood that it will be followed, by influencing comprehension, recall, planning, and behaviour. For example, work by Philip Ley shows that using specific concrete statements increases the extent to which information is both understood and remembered. ${ }^{23}$ Individuals who intend to change behaviour are more successful if they have a specific behavioural plan. ${ }^{4} \mathrm{~A}$ recognised technique of behaviour modification is to define the target behaviour in specific and concrete terms. ${ }^{5}$

In a study of attributes of 10 national clinical guidelines, general practitioners followed the guidelines on $67 \%$ of occasions if they were concrete and precise but on only $36 \%$ of occasions when they were vague and non-specific. ${ }^{6}$ Implementation of guidelines might therefore be improved by defining the crucial elements precisely. ${ }^{67}$ Clear specification also makes it possible to assess whether the guideline has been followed. ${ }^{1}$

\section{Specifying behaviour}

Recommendations in guidelines are rarely specified in precise behavioural terms such as what, who, when, where, and how. An example is the first clinical guideline to be developed and published by the National Institute for Clinical Excellence, which has been widely circulated throughout the NHS. ${ }^{8}$ Despite the high quality review of evidence underpinning the guideline, the recommendations are not behaviourally specific. The guideline is long, with the recommendations in the short form exceeding 20 pages. This may result in recommendations getting lost. ${ }^{9}$ Furthermore, the style of presentation of the guidelines does not optimise implementation.

Table 1 gives the main (grade $\mathrm{A}$, based on randomised controlled trials) recommendations with suggestions on how they could be behaviourally specified. We have limited the suggestions to what and who,

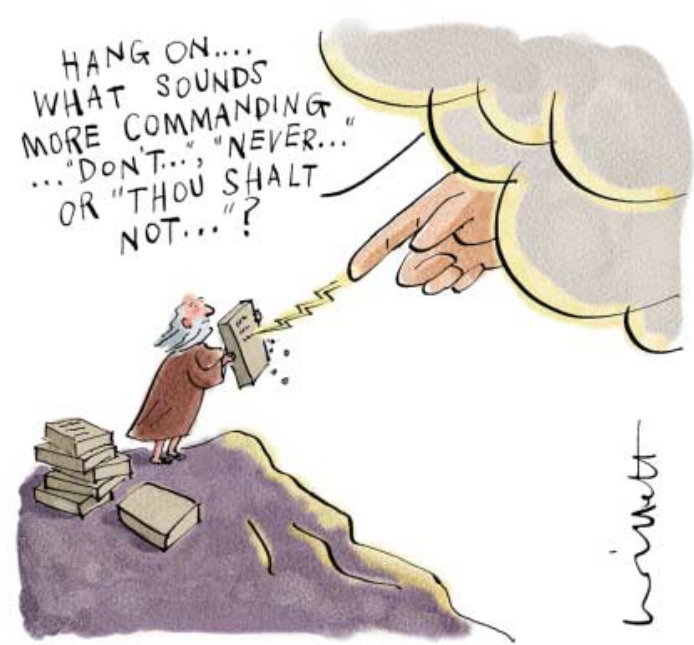

Centre for

Outcomes Research

and Effectiveness,

Department of

Psychology,

University College

London, London

WC1E 7HB

Susan Michie

reader in clinical

health psychology

School of

Psychology, King's

College, University

of Aberdeen,

Aberdeen,

AB24 2UB

Marie Johnston

professor of psychology

Correspondence to:

S Michie

s.michie@ucl.ac.uk

but where, when, and how could be similarly added. We have used active verbs rather than general exhortations (should) or descriptions (may). Translating the recommendations in this way revealed two areas of uncertainty. In the first example, it is unclear whether day hospital treatment should be encouraged or merely offered; in the fifth, it is unclear whether depot preparations should be prescribed for everyone with schizophrenia.

Constructing the who component of the recommendation showed that the specification of the health professional is slightly different in each of the five recommendations. In practice, the same person may carry out each of the defined functions, but it could be two or more people. The person specification clarifies the initial steps of implementing the guideline for trust boards.

This analysis suggests that these guidelines may have been developed to offer general guidance rather than prescriptive action. However, similar patterns are present in the subsequent three evidence based guidelines published by the National Institute for Clinical Excellence. Table 2 gives one grade A recommendation from each guideline and illustrative questions that remain unanswered by the guidelines' wording.

\section{Analysing and changing behaviour}

Specifying behaviour precisely serves two functions in implementing guidelines. Firstly, as described above, it makes implementation more likely; there is greater clarity about what is required and greater certainty about whether it has been accomplished. Secondly, it allows a systematic investigation of the way that the behaviour is linked to what occurs before (antecedents) and what occurs after (consequences). Antecedents and consequences can operate as either facilitators of, 
Table 1 Suggested amendments to published guidelines on schizophrenia to improve specification of behaviour

\begin{tabular}{|c|c|c|}
\hline \multirow[b]{2}{*}{ Published main recommendations ${ }^{8}$} & \multicolumn{2}{|c|}{ Behavioural specifications } \\
\hline & What & Who \\
\hline $\begin{array}{l}\text { Acute day hospitals should be considered as a clinical and } \\
\text { cost effective option for the provision of acute care, both as } \\
\text { an alternative to acute admission to inpatient care and to } \\
\text { facilitate early discharge from inpatient care }\end{array}$ & $\begin{array}{l}\text { Encourage [offer?] acute day hospital treatment to inpatients } \\
\text { or those facing acute admission to inpatient care }\end{array}$ & Service manager responsible for making treatment decision \\
\hline $\begin{array}{l}\text { Cognitive behavioural therapy (CBT) should be available as a } \\
\text { treatment option for people with schizophrenia }\end{array}$ & $\begin{array}{l}\text { Offer cognitive behavioural therapy to everyone with } \\
\text { schizophrenia }\end{array}$ & $\begin{array}{l}\text { Trust board and health professional responsible for offering } \\
\text { treatment options }\end{array}$ \\
\hline $\begin{array}{l}\text { Family interventions should be available to the families of } \\
\text { people with schizophrenia who are living with or who are in } \\
\text { close contact with the service user }\end{array}$ & $\begin{array}{l}\text { Offer family intervention to all those in close contact with } \\
\text { someone with schizophrenia }\end{array}$ & $\begin{array}{l}\text { Trust board and health professional responsible for offering } \\
\text { interventions to people in close contact with someone with } \\
\text { schizophrenia }\end{array}$ \\
\hline $\begin{array}{l}\text { When providing family interventions, service users and their } \\
\text { carers may prefer single family interventions rather than } \\
\text { multifamily group interventions }\end{array}$ & $\begin{array}{l}\text { Give information about and offer a choice of single family or } \\
\text { multifamily group interventions when offering family } \\
\text { interventions to people with schizophrenia or their carers }\end{array}$ & $\begin{array}{l}\text { Health professional responsible for providing information to } \\
\text { service users and carers about family interventions }\end{array}$ \\
\hline $\begin{array}{l}\text { For optimum effectiveness in preventing relapse, depot } \\
\text { preparations should be prescribed within the standard } \\
\text { recommended dosage and interval range }\end{array}$ & $\begin{array}{l}\text { Prescribe depot preparations within the standard } \\
\text { recommended dose and interval range [for all those with } \\
\text { schizophrenia?] }\end{array}$ & Psychiatrist responsible for drug treatment \\
\hline
\end{tabular}

Table 2 Illustrative grade A recommendations from three National Institute for Clinical Excellence guidelines and questions about behavioural specifications

\begin{tabular}{|c|c|c|c|}
\hline \multirow[b]{2}{*}{ Guideline } & \multirow[b]{2}{*}{ Published recommendation } & \multicolumn{2}{|c|}{ Questions about behavioural specifications } \\
\hline & & What? & Who? \\
\hline $\begin{array}{l}\text { Prevention of healthcare associated infection } \\
\text { in primary and community care }{ }^{10}\end{array}$ & $\begin{array}{l}\text { Hands must be decontaminated, preferably } \\
\text { with an alcohol based hand rub unless hands } \\
\text { are visibly soiled, between caring for different } \\
\text { patients or between different care activities for } \\
\text { the same patient. } \\
\text { (to be applied by all healthcare personnel to } \\
\text { the care of patients in community and primary } \\
\text { care settings) }\end{array}$ & $\begin{array}{l}\text { Decontamination is the endpoint, but what } \\
\text { behaviour is being recommended? The } \\
\text { behaviour could be specified—eg covering all } \\
\text { hand, nail, and wrist surfaces with a } \\
\text { decontaminating agent }\end{array}$ & $\begin{array}{l}\text { Does this apply only to those delivering direct } \\
\text { services to patients or also to those working } \\
\text { in the area in which services are delivered to } \\
\text { patients (porters, domestic staff, those } \\
\text { delivering home aids, etc)? }\end{array}$ \\
\hline $\begin{array}{l}\text { Triage, assessment, investigation, and early } \\
\text { management of head injury }{ }^{11}\end{array}$ & $\begin{array}{l}\text { The current primary investigation of choice for } \\
\text { the detection of acute clinically important } \\
\text { brain injuries is CT imaging of the head }\end{array}$ & $\begin{array}{l}\text { The behaviour is computed tomography of the } \\
\text { head, but when, and under what clinical } \\
\text { conditions, is it being recommended? }\end{array}$ & $\begin{array}{l}\text { Who decides whether acute clinically } \\
\text { important brain injuries should be } \\
\text { investigated? }\end{array}$ \\
\hline $\begin{array}{l}\text { Management of chronic heart failure in adults } \\
\text { in primary and secondary care }{ }^{12}\end{array}$ & $\begin{array}{l}\text { Heart failure care should be delivered by a } \\
\text { multidisciplinary team with an integrated } \\
\text { approach across the healthcare community }\end{array}$ & $\begin{array}{l}\text { What behaviours are required to show that an } \\
\text { integrated approach has been taken (eg } \\
\text { reading the same notes, holding joint } \\
\text { meetings)? }\end{array}$ & $\begin{array}{l}\text { Who, and what disciplines, are required to } \\
\text { constitute a multidisciplinary team? }\end{array}$ \\
\hline
\end{tabular}

or barriers to, behaviour. Changing these is a powerful way of changing behaviour. The scientific analysis of the relations between antecedents, behaviour, and consequences $(\mathrm{ABC})$ is known as behavioural analysis or functional analysis ${ }^{13}$ and was developed within clinical psychology. $^{14}$

Examples of manipulating antecedents and consequences and observing the effect on a defined behaviour come from two experimental studies of referral rates of general practitioners. The first introduced an antecedent cue to increase referral rates for mammography. ${ }^{15}$ The cue was a sticker in a schematic breast shape with a bright orange dot placed on the charts of women aged over 50 years. Referral rates were higher in this condition than in the control condition.

The second study evaluated an intervention to reduce the frequency that general practitioners ordered radiography of the lumbar spine and knee. ${ }^{16}$ Each time the general practitioner ordered an $\mathrm{x}$ ray examination, the results were accompanied by an educational sticker that reiterated the guidelines. This reduced the frequency of ordering by $20 \%$, in line with the recommendations of the Royal College of Radiologists.

\section{Conclusion}

Ample evidence exists to support the argument that the simplest, most cost effective intervention to increase the implementation of guidelines is rewriting

\section{Summary points}

Psychological research shows that the more precisely behaviours are specified, the more they are likely to be carried out

Rewriting guidelines to increase behavioural specificity may be the simplest, most effective method of increasing implementation

Specifying what, who, when, where, and how will assist implementation

Behavioural analysis of the controlling antecedents and consequences of implementation may help develop effective interventions

guidelines in behaviourally specific terms. Future research could compare the effectiveness of rewritten guidelines with that of the original before assessing more complex interventions. Interventions should be developed on the basis of an analysis of the antecedents and consequences controlling implementation behaviours. This analysis should be informed by relevant psychological theory.

Contributors and sources: SM and MJ are chartered health and clinical psychologists. Their research has covered many areas of health, illness, and the healthcare system, including the applica- 
tion of psychological theory to the implementation of evidence based practice. This article was informed by discussions in a seminar series funded by the British Psychological Society (the scientific understanding of the psychological processes involved in the implementation of evidence based practice in health services) and in an advisory group to a programme grant funded by the Medical Research Council (process modelling in implementation research: selecting a theoretical basis for interventions to change practice; MJ, Martin Eccles, Jeremy Grimshaw, Nigel Pitts, Nick Steen).

\section{Competing interests: None declared.}

1 Grimshaw JM, Shirran L, Thomas R, Mowatt G, Fraser C, Bero L, et al Changing provider behaviour: an overview of systematic reviews of interventions. Med Care 2001;39(suppl 2):2-45.

2 Ley P. Communicating with patients. London: Chapman and Hall, 1988.

3 Ley P. Written communication. In: Baum A, Newman S, Weinman J, West R, McManus C, eds. Cambridge handbook of psychology, health and medicine. Cambridge: Cambridge University Press, 1997:331-4.

4 Gollwitzer PM. Implementation intentions: strong effects of simple plans. Am Psychol 1999;54:493-503.

5 Kazdin AE. Behaviour modification in applied settings. Belmont, CA Wadsworth/Thomson Learning, 2001.

6 Grol R, Dalhuijsen J, Thomas S, Veld C, Rutten, G, Mokkink H. Attributes of clinical guidelines that influence use of guidelines in general practice: observational study. BMJ 1998;317:858-61.

7 Grol R. Beliefs and evidence in changing clinical practice. BMJ 1997;315:418-21.

8 National Institute for Clinical Excellence. Schizophrenia: core interventions in the treatment and management of schizophrenia in primary and secondary care. Clinical guideline 1. London: NICE, 2002.

9 Eccles, M. Deriving recommendations in clinical practice guidelines. Qual Saf Health Care (in press).

10 National Institute for Clinical Excellence. CG2-Infection control, prevention of healthcare-associated infection in primary and community care (NICE guideline). www.nice.org.uk/Docref.asp?d = 71777 (accessed 6 Jan 2003).

11 National Institute for Clinical Excellence. CG4 - Head injury: triage, assessment, investigation and early management of head injury in infants, children and adults (NICE guideline). www.nice.org.uk/Docref.asp?d $=74656$ (accessed 6 Jan 2003).

12 National Institute for Clinical Excellence. CG3-Chronic heart failure: management of chronic heart failure in adults in primary and secondary care (NICE guideline) www.nice.org.uk/Docref.asp?d = 79726 (accessed 6 Jan 2003).

13 Cone JD. Issues in functional analysis in behavioural assessment. Behav Res Ther 1997;35:259-75.

14 Kanfer FH, Saslow G. Behavioral diagnosis. In: Franks CM, ed. Behavior therapy: appraisal and status. New York: McGraw-Hill, 1969:417-44.

15 Grady KE, Lemkau JP, Lee NR, Caddell C. Enhancing mammography referral in primary care. Prev Med 1997;26:791-800.

16 Eccles M, Steen N, Grimshaw G, Thomas L, McNamee P, Soutter J, et al. Effect of audit and feedback and educational reminder messages on primary care radiology referrals. Lancet 2001;357, 1406-9.

(Accepted 8 December 2003)

\section{A memorable patient}

\section{A nanny's stamina}

When I started as a senior house officer on the unit she was practically mute: the effort of speaking was immense, she could give none of the usual conversational cues, and it was difficult to maintain such a one sided encounter for long. She sat on the ward throughout the day, eschewing the group activities, her face conveying silent despair. "I just can't do anything," she would manage. Later she recalled how she had felt the predicament of others trying to draw her out, but when I asked what she felt her attendants should do in that situation, she replied, "You can't, there's nothing anyone can do. When someone's like that you just have to leave them." None the less, I went every day to see her, asking her how she was and taking blood to check the levels of her various antidepressants.

She disliked taking the tablets, and we kept increasing them. She acquiesced to this with that self contained sense of having to suffer fools gladly that only the Scots can truly master. Of course, she was right, and later we tipped her into mania,

embarrassing her greatly at the things she then said. To begin with, as the drugs slowly took effect, she began to fret about her hair, which by then needed washing, and the time she needed to get ready in the morning. But then, majestic in intricate cardigans, she took up her knitting, and as she emerged so did part of her story, or that part of an era when she had been in control.

The notes gave the long history of her manic depressive illness and described her as an "ex-nanny." Feeling at the time that I was having more than my fair share of nanny troubles, I was interested in her as a relic from a time when nannies seemed to me to have been real nannies. This encouraged her. She spoke of coming down from Scotland to the south coast of England with her employers to look after their four children. She described the large house, trimmed hedges, her uniform, and the mother who dressed elegantly to receive and visit friends for lunch. She recounted her day off each week, the long hours, and the evenings spent starching and pressing the children's clothes. Of course, she had an under-nanny to help her with this, but, she intimated, young girls these days didn't know their luck.

From my experience, I tended to agree, but this domestic scene was later shattered. One day in this household she had been unwell with a fever heralding pneumonia. The mother, pregnant with her fifth child, had visited the nursery, and the children had reported that Nanny was unwell. "No she isn't. She's just pretending," the mother had replied.

Nanny had bit her lip, finished her day's work, and later confronted the mother with the news that she was leaving. "You should not have talked to me like that in front of the children," she said.

The children cried all that night, and in the morning the mother was contrite. She had not really meant it. "How am I to cope with this next baby?" she wailed.

"You should have thought of that in the first place," came Nanny's retort. Off she sailed without references to land another job in no time.

Back on the ward, she smiled a sad resigned smile. The stamina that kept her through the ups and downs of her current illness was part of the same strength of character that earlier meant she had not been able to know her place.

Elizabeth Davies senior clinical research fellow, London

We welcome articles up to 600 words on topics such as A memorable patient, A paper that changed my practice, My most unfortunate mistake, or any other piece conveying instruction, pathos, or humour. Please submit the article on http://sdubmit.bmj.com Permission is needed from the patient or a relative if an identifiable patient is referred to. We also welcome contributions for "Endpieces," consisting of quotations of up to 80 words (but most are considerably shorter) from any source, ancient or modern, which have appealed to the reader. 